\title{
MATHEMATICAL MODEL OF PHYSICAL PROPERTIES CHANGE OF COCONUT SAP IN THE VACUUM EVAPORATOR
}

\author{
Febryan Kusuma Wisnu ${ }^{1 凶}$, Sri Rahayoe ${ }^{2}$, Rizza Wijaya ${ }^{3}$, Mareli Telaumbanua ${ }^{1}$, Agus \\ Haryanto ${ }^{1}$ \\ ${ }^{1}$ Department of Agricultural Engineering, Faculty of Agriculture, Universitas Lampung \\ ${ }^{2}$ Department of Agricultural Engineering and Biosystem, Faculty of Agricultural Technology, Universitas \\ Gadjah Mada \\ ${ }^{3}$ Department of Agricultural Technology, Politeknik Negeri Jember \\ ${ }^{\square}$ Komunikasi Penulis, email: febryankusumawisnu@gmail.com \\ DOI:http://dx.doi.org/10.23960/jtep-lv10i2.252-262
}

Naskah ini diterima pada 25 Februari 2021; revisi pada 20 Maret 2021;

disetujui untuk dipublikasikan pada 8 April 2021

\begin{abstract}
The potential of brown sugar as a substitute for granulated sugar is enormous considering the abundant coconut sap production. However, the quantity of brown sugar production through the traditional method is one of the main obstacles. This study used a vacuum evaporator that emphasizes the hygienic and effective mass production of brown sugar. For this reason, it is necessary to approach changes in the physical properties of sap juice during the cooking process. This knowledge is indispensable in the cooking process, which involves the proper evaporation and crystallization of brown sugar. This research is devoted to determining the viscosity, density, and dissolved solids expressed in Brix and proposes a mathematical model to predict the physical properties during the evaporation process of brown sugar as a function of the initial concentration the solution before proceeding to the crystallization process. Results confirm that the prediction model for Brix is $C_{\theta}=\left(C_{0}-\right.$ $\left.C_{\mathrm{e}}\right) \cdot \exp (0.0067 \cdot t)+C_{\mathrm{e}}$, the model for viscosity $\mu_{\theta}=\mu_{\mathrm{o}} \cdot \exp (0.011 \cdot t)$, and $\rho_{\mathrm{e}}=(0.44996 \cdot t)+\rho_{0}$ for the density prediction model. The resulted mathematical model can accurately predict the rate of change in coconut sap's physical properties, indicated by the high coefficient of determination $\left(\mathrm{R}^{2}\right)$.
\end{abstract}

\section{Keywords : brix, brown sugar, density, vacuum evaporator, viscosity}

\section{INTRODUCTION}

Coconut sap is a clear liquid that comes out of coconut flowers whose buds have not yet opened. When it is fresh, the sap has a sweet, fragrant, and colorless taste. The sweetness of coconut juice is a relatively high content of sucrose. Xia et al. (2011) stated that sap has a sucrose content of $14 \%$ when it is freshly tapped. As the primary raw material in making palm sugar, the sap is also used to produce brown sugar. The most significant difference between palm sugar and brown sugar is the water content. According to Santoso (1993), the difference occurs due to type method. The brown sugar undergoes more extended handling so that the amount of water evaporates more than the palm sugar. Burhanuddin (2005) stated that the brown sugar from Rangkasbitung contained 73\% Brix, $0.03 \%$ moisture content, and had a grain size of $0.31 \mathrm{~mm}$.
The potential of brown sugar as a substitute for granulated sugar is enormous considering the abundant coconut sap production. However, the obstacle faced is the production process of brown sugar, most of which is still done traditionally. Combustion smoke from traditional stoves can cause environmental pollution and disrupt ecosystems by adding toxic residues to plants (Telaumbanua et al, 2021). The other disadvantage of this traditional method is that the quantity of production is still minimal because the average farmer uses a traditional skillet that can only produce a maximum of $5 \mathrm{~kg}$ of coconut sugar at one time.

To overcome this problem, a low-temperature of 100-liter capacity vacuum evaporator has been designed due to heat-sensitive properties of food products. The evaporation process should use low temperatures to avoid product degradation (Singh et al, 1992). Lowering the 
boiling point of a solvent or liquid is done by reducing the pressure above the liquid's surface to be lower than the atmospheric pressure, or called a vacuum (Wirakartakusumah, 1989). According to Heldman (2012), the heating process of food at high temperatures during the evaporation process able to loss of taste and decreases the product quality. The evaporation process during brown sugar cooking, able to concentrate the diluted solution into more concentrated sugar. Afterward, the density and viscosity will be increase and affect to the liquid's physical properties (Geankoplis, 1995).

The coconut sap evaporation process carried out in this study used a low-temperature vacuum evaporator. This aims of evaporation processes in order to maintain the food quality and increase the production quantity in one cycle (Hariono et al., 2018). Initially, an approach is made to changes in materials' physical properties during the cooking process. This knowledge is indispensable in the cooking process, which involves the proper evaporation of coconut sap. Mathematical predictions of food products can be made using the Artificial Neural Network model (Haryanto et al., 2020), the theoretical approach to kinetics, and Newton's Cooling Law's analogy.

This research is devoted to determining the viscosity, density, and dissolved solids expressed in Brix. Based on these results, a mathematical model is then compiled to predict the brown sugar evaporation process's physical properties as a function of the initial concentration of the solution before proceeding to the crystallization process.

\section{MATERIALS AND METHODS}

\subsection{Vacuum Evaporator}

The equipment used in this study was a sugar processing unit consisting of a boiler and an evaporator (Figure 1). The resulted hot steam comes from the boiler by utilizing the boiler water boiling process.

The dimensions of this evaporator are as follows, the length of the coil is 20 meters with several ten coils, each coil is $3 \mathrm{~cm}$ apart, and the coil diameter is $4 \mathrm{~cm}$. Meanwhile, the evaporator's height, which consists of tubes and cones, is 90 $\mathrm{cm}$ and $12 \mathrm{~cm}$, respectively, so the evaporator's overall size is $112 \mathrm{~cm}$. Besides that, this evaporator has a diameter of $50 \mathrm{~cm}$. This evaporator consists of several operating functions: a heat exchanger device, a condenser, and a vacuum generator.

\subsection{Data Collection Procedure}

The material used in this study was fresh coconut sap with a volume of 100 liters for three replications. Both coconut sap and palm sugar juice are directly to ferment. This fermentation occurs due to the invertase enzyme activity, which is produced by microbes that contaminate the sap and palm sugar juice. These microbes include Saccharomyces cerevisiae, able to conduct the hydrolysis of sucrose and reduce the sugar concentration (Marsigit, 2005).

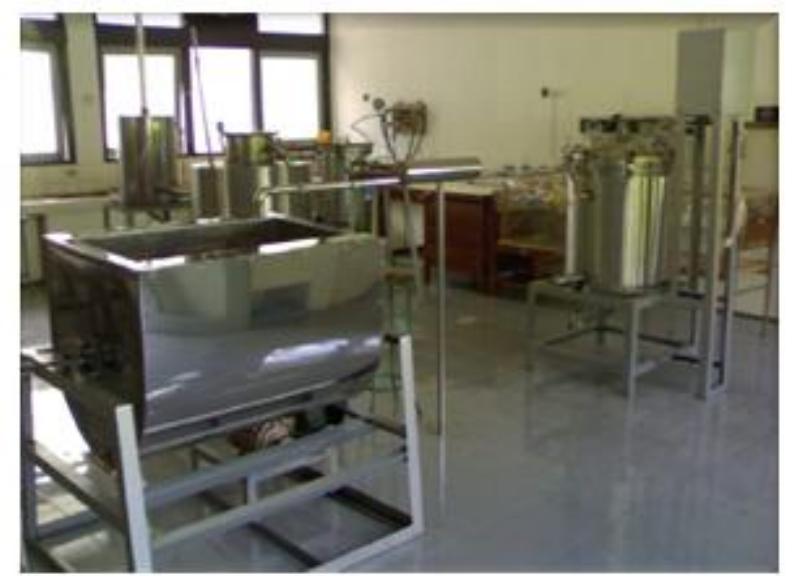

Figure 1. Boiler (Left) and Brown Sugar Processing Devices (Right) 
Meanwhile, according to Hamzah and Hazbullah (1997), the sucrose content will decrease rapidly in the fermentation. This change is followed by reduced $\mathrm{pH}$ due to an increase in acid content, namely acetic acid, lactic acid, and tartaric acid. Therefore, data collection is carried out immediately after the sap is taken from the farmers.

In this study, the evaporation process was carried out at a temperature of $140^{\circ} \mathrm{C}$ and a pressure of $2 \mathrm{~atm}$. When the evaporator's cooking process occurs, the material's initial temperature is measured, and the pressure and temperature of the heater are recorded by looking at the indicator installed on the boiler. The Brix content of the material was measured from $t=0$ using a refractometer. For measurement of Brix levels, it is carried out every 15 minutes since the initial minute. After reaching 180 minutes, the Brix measurement is carried out every 10 minutes until the time specified. Measurements are made by taking a sample of material from the evaporator output pipe of approximately $0,3 \mathrm{ml}$ of the solution to the refractometer sensor.

The same measurement is applied to the viscosity and density of the sap juice. The sampling time is uniform so that the heat and pressure lost when the sample output valve is opened is not too large. Sampling as much as $440 \mathrm{ml}$ and poured into a transparent cup. Then successively measured and recorded the viscosity and density of each time.

\subsection{Data Analysis}

\subsubsection{Brix}

Brix data during evaporation is plotted into a graph where the cooking time is the $\mathrm{x}$-axis, and the Brix $\left(C_{\theta}\right)$ is the y-axis. While the $C e$ equilibrium Brix is determined by the results of the highest observed degree of Brix measured. Meanwhile, the constant change rate of Brix $\left(k_{c}\right)$ of the observations is determined using a graph between $\ln \left\{\left(C_{\theta}-C_{\mathrm{e}}\right) /\left(C_{0}-C_{\mathrm{e}}\right)\right\}$ vs. $\theta$. This analysis is determined based on the analogy of Newton's Cooling Law, which is begun from Eq. (1) or Eq. (2):

$$
\frac{d C}{d \theta}=-k_{c} \cdot\left(C-C_{e}\right)
$$

$$
\frac{d C}{\left(C-C_{\varepsilon}\right)}=-k_{c} \cdot d \theta
$$

After integration at initial Brix $C_{0}$ to equilibrium Brix $C_{e}$ and cooking time from 0 to $\theta$, we will have Eq. (3) or Eq. (4):

$$
\begin{aligned}
& \ln \left(\frac{C_{\theta}-C_{e}}{C_{0}-C_{e}}\right)=-k_{c} \cdot \theta \\
& \frac{C_{\theta}-C_{\varepsilon}}{C_{0}-C_{\varepsilon}}=e^{-k_{\varepsilon} \cdot \theta}
\end{aligned}
$$

where $C_{\theta}$ is the Brix at $\theta(\%), C_{0-}$ is the initial $\operatorname{Brix}(\%), C_{\mathrm{e}}$ is the equilibrium Brix (\%), $k_{c}$ is the constant change rate of Brix, and $\theta$ is the cooking time in minutes.

\subsubsection{Viscosity}

The viscosity data obtained from the measurement results are presented in a graph of the relationship between cooking time $\theta$ and viscosity $\theta_{\theta}$. Meanwhile, the constant change rate of viscosity $k$ is determined by plotting the relationship between $\ln \left(\mu_{\theta} / \mu_{0}\right)$ and cooking time $\theta$ for each replication. Next, the predicted $k_{\mu}$ value is substituted into the equation, so that the predictive viscosity $\left(\mu_{\theta}\right)$ is obtained. The graph of the change in viscosity from the observations obtained is exponential, so the viscosity of coconut sap during evaporation is determined using the first-order kinetics theory formula $(n=1)$, as follows:

$$
\frac{d \mu}{d \theta}=-k_{\mu} \mu^{n}
$$

For $n=1$ we can rearrange Eq. (x) to be:

$$
\frac{d \mu}{\mu}=-k_{\mu} \cdot d \theta
$$

After integrating at ${ }_{0}$ to ${ }_{\theta}$ for the left side and $\theta=0$ to $\theta=\theta$ for the right side we can show that viscosity can be presented as in Eq. (7) or Eq. (8):

$$
\begin{aligned}
& \ln \frac{\mu_{\theta}}{\mu_{0}}=-k_{\mu} \cdot \theta \\
& \frac{\mu_{\theta}}{\mu_{0}}=e^{-k_{\mu} \cdot \theta}
\end{aligned}
$$

where $\mu_{\theta}$ is the viscosity at a certain $\theta$ (mPa.s), $\mu_{0}$ is the initial viscosity (mPa.s), $k_{\mu}$ is the constant change of viscosity, while $\theta$ is the cooking time in minutes. 


\subsubsection{Density}

The density measurement data obtained during cooking is also presented in a graph of the relationship between cooking time $\theta$ and density $\rho_{\theta}$. At the same time, the constant change rate of density $k_{\rho}$ is determined by the graph of the relationship between $\rho_{\theta-} \rho_{0}$ and cooking time $\theta$ for each replication. The graph of the change in density observed in this study has a linear trend, so the density of coconut juice during evaporation is determined using the formula for the theory of zero-order kinetics ( $n$ $=0$ ), as follows:

$$
\frac{d \rho}{d \theta}=-k_{\rho} \cdot \rho^{n}
$$

For $n=0$ we can rearrange Eq. (9) into:

$$
d \rho=-k_{\rho} \cdot d \theta
$$

Following integration at $\rho_{0}$ to $\rho_{\theta}$ and cooking time 0 to $\theta$ we will end with Eq. (11):

$$
\rho_{\theta}-\rho_{0}=-k_{\rho} \cdot \theta
$$

where $\rho_{\theta}$ is the density at a certain $\theta\left(\mathrm{kg} / \mathrm{m}^{3}\right)$, $\rho_{0}$ is the initial density $\left(\mathrm{kg} / \mathrm{m}^{3}\right), k_{\rho}$ is the constant change rate of density, while $\theta$ is the cooking time in minutes.

\section{RESULT AND DISCUSSION}

\subsection{Brix During Process}

\subsubsection{Effect of time changes on Brix}

In preliminary studies, the Brix changes were observed from the start of the intake until the evaporation process was complete. This aims to determine the initial Brix and evaporation time needed to reach a certain Brix. This reference is still used in the primary research so that the evaporation results can be maximized and then proceed to the crystallization process. Table 1 shows the initial Brix of sap's measurement results for each replication.
When the evaporation process occurs, the sap juice receives heat from the coil, fed by hot steam from the boiler. The occurrence of evaporation can indicate the increase in Brix. The boiling point of the solute, which is higher than the solvent, causes the sap's thickening due to the evaporation of most of the solvent, in this case, water. The thickened juice will cause the solution's concentration to increase so the number of dissolved solids will also increase. The rate of change of the Brix is shown in Figure 2. The evaporation process ends when the total dissolved solids in the sap are between $41-48 \%$. If this value has been reached, the solution can be continued to the next process, crystallization.

\subsubsection{The Brix Change Rate}

The Brix change rate can be interpreted as the increasing Brix of the juice per unit time due to heating. The constant rate of change Brix $\left(k_{c}\right)$ states the velocity of the water's mass leaving the sap juice. The constant of Brix changing rate in the sap juice was analyzed using the highest Brix obtained in replication 3 , that is $C=46.6$. Brix equilibrium is a condition where there is no mass transfer of water both to and from the evaporator's air. Furthermore, the constant of Brix changing rate is determined through a graph of the coagulation time relationship $(\theta)$ to $\ln \left\{\left(C_{\theta}-C_{e}\right) /\left(C_{o}-C_{e}\right)\right\}$ as shown in Figure 3 .

Based on Figure 3, the constant of Brix changing rate for replication 3 is $0.0054 \mathrm{~min}^{-1}$ (Table 2). Then the observed Brix's constant change rate is substituted for equation 1 so that the predicted Brix is obtained, which is from now on referred to as the Brix prediction based on the constant of observed Brix changing rate.

\subsubsection{The Brix Prediction}

Based on the constant change rate of the observed Brix shown in Table 2, the Brix prediction can be determined by substituting

Table 1. The Initial Brix Content of the Sap

\begin{tabular}{lcc}
\hline & Reps & Brix (\%) \\
\hline \multirow{3}{*}{ Coconut sap } & 1 & 20,1 \\
& 2 & 20,3 \\
& 3 & 19,9 \\
\hline
\end{tabular}




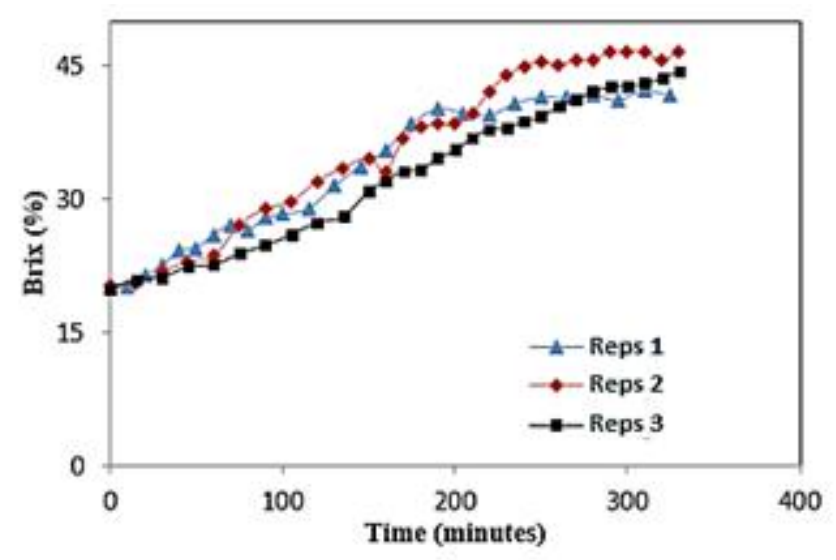

Figure 2. Brix Changes During Time at $140^{\circ} \mathrm{C}$ and $2 \mathrm{~atm}$

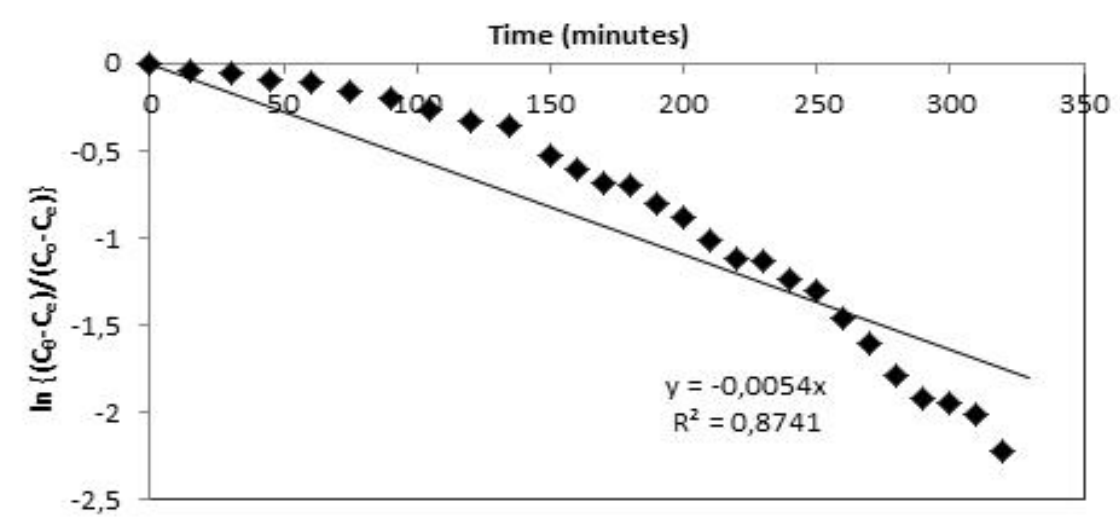

Figure 3. Graph of Coagulation Time $(\Theta)$ Versus $\ln \left\{\left(C_{\theta}-C_{e}\right) /\left(C_{0}-C_{e}\right)\right\}$ Coconut Sap Juice

(Replication 3)

Table 2. The Constant Observed Brix Changing Rate at $140^{\circ} \mathrm{C}$ and $2 \mathrm{~atm}$

\begin{tabular}{cccc}
\hline & \multirow{2}{*}{ Reps } & \multicolumn{2}{c}{ Observed $\boldsymbol{k}\left(\mathbf{m i n}^{\mathbf{1}}\right)$} \\
\cline { 2 - 4 } Coconut sap & 1 & 0.0059 & Average \\
& 2 & 0.0089 & 0.0067 \\
& 3 & 0.0054 & \\
\hline
\end{tabular}

these values into the equation of Brix prediction $\left(\mathrm{C}_{\theta}\right)(\%)$, as follows:

$$
C_{\theta}=\left\{\left(C_{0}-C_{e}\right) \cdot e^{(0.0067 \cdot t)}\right\}+C_{e}
$$

Furthermore, the measured (observed) Brix is compared with the Brix prediction through time, as shown in Figure 4a.

The figure shows that the predicted changes in the Brix are not much different from the changes in the measured Brix (observed). Meanwhile, Figure 4 shows the comparison between the observed Brix and the predicted Brix where the points formed are adjacent to the linear line equation $y=m x$. This indicates that the change in the predicted Brix is not significantly different from the change in the measured Brix from the measurement (observation) where the predicted Brix is calculated using a constant change rate for the observed Brix. The following table is gradients and the coefficient of determination $\left(R^{2}\right)$ for each replication.

Table 3 shows that the line equation's gradient value for the 100-liter sap juice varies from 0.9505 to 0.9743 . The line equation's gradient value formed between the observed Brix and the predicted Brix shows that the difference between the measured (observed) Brix and 
calculated (predicted) Brix is very small. The $\mathrm{R}^{2}$ value that close to 1 also indicated that the predicted Brix's values and the observed Brix are almost linear, as shown in Figure 4b.

\subsection{Viscosity During Process}

\subsubsection{Effect of Time Changes On Viscosity}

Measuring coconut sap's viscosity in this study using a Viskotester VT-03F, which has limited ability to measure high viscosity materials but thickens using an evaporator, viscosity measurement can still be done optimally because the viscosity limit of the material is still low. Based on the measurement results, the change in the sap juice's viscosity during thickening can be seen in the Figure 5. The figure shows that the solution's viscosity increases with time and shows a difference in the change in viscosity for each test. This viscosity data collection follows the thickening time of the Brix. If the Brix has reached a predetermined value, then the viscosity data collection is also stopped. Differences in the sap's quality caused the difference in the increase in viscosity between replicates.

\subsubsection{The Viscosity Change Rate}

As the change rate of Brix, the viscosity change rate during thickening is also defined as increasing the viscosity of the material per unit time due to heating. The constant change rate in viscosity $\left(k_{\mu}\right)$ expresses the rate at which water mass leaves the material during heating which causes the viscosity of the solution to increase

Table 3. Gradient $(m)$ and $\mathrm{R}^{2}$ Values Between Predicted Brix and Observed Brix

\begin{tabular}{cccc}
\hline & Reps & $\boldsymbol{m}$ & $\mathbf{R}^{2}$ \\
\hline \multirow{3}{*}{ Coconut sap } & 1 & 0.9743 & 0.9499 \\
& 2 & 0.9505 & 0.8501 \\
& 3 & 0.9610 & 0.8890 \\
\hline
\end{tabular}

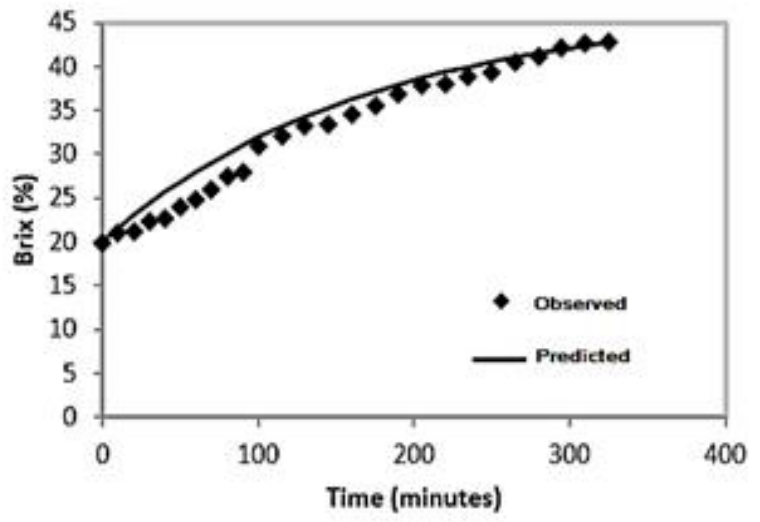

a

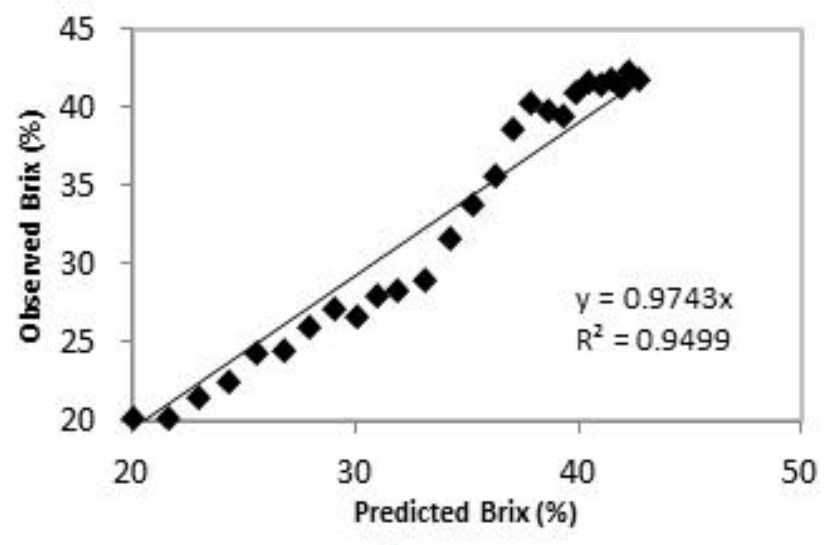

b

Figure 4. (a) Changes of the Observed Brix and Predicted Brix Versus Time and (b) Comparison Between Predicted Brix and Observed Brix

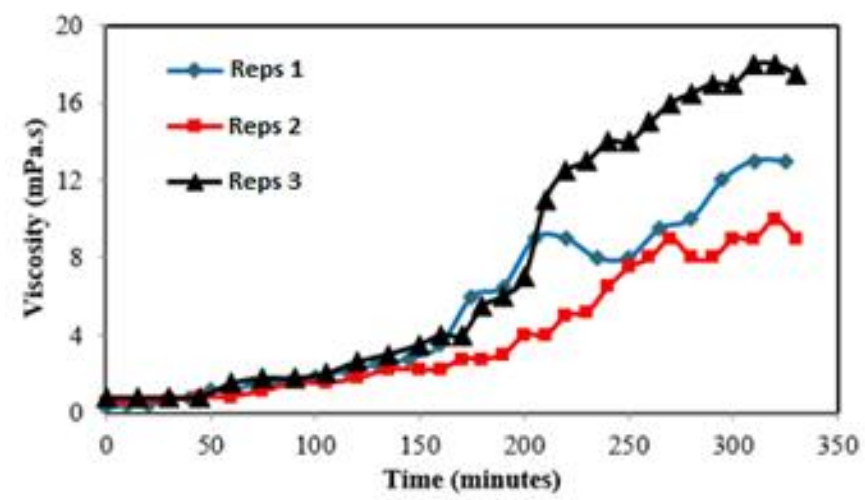

Figure 5. Viscosity Changes During Time at $140^{\circ} \mathrm{C}$ and $2 \mathrm{~atm}$ 
with time. The constant change rate in viscosity $\left(k_{\mu}\right)$ is determined by Eq. (7) by plotting a graph of the relationship between coagulation time $(\theta)$ to $\ln \left\{\left(\mu_{\theta}\right) /\left(\mu_{0}\right)\right\}$, as shown in Figure 6 .

The equation of the line in the figure shows that the constant of rate change in viscosity is 0.0099 $\mathrm{min}^{-1}$. Furthermore, the constant of rate change in viscosity is called the constant of observed viscosity changing rate, presented in Table 4 .

The constant of observed viscosity changing rate is then substituted for equation 2 so that the predictive viscosity equation is obtained, as shown by the following equation.

$$
\mu_{\theta}=\mu_{0} \cdot \exp (0,011 . t)
$$

\subsubsection{The Viscosity Prediction}

Based on Equation 5, the predictive viscosity for the solution during the evaporation process can be determined, which is then carried out by plotting the measured (observed) viscosity with the predicted viscosity, as shown in Figure 7. Figure 7 shows that the predicted viscosity is almost close to the observed viscosity, but this only happens when the sap's viscosity has not experienced a sufficiently large increase in viscosity. Meanwhile, when the observed viscosity reaches a high increase, the predicted viscosity is far from the observed viscosity.

Meanwhile, Figure 8 shows the comparison between the predicted viscosity of the measured viscosity, based on the coefficient of determination $\left(\mathrm{R}^{2}\right)$ almost close to 1 for the sap juice, namely $0.7042-0.8674$. This shows that the points formed between the measured (observed) viscosity and calculated (predicted) results are almost adjacent to the linear line.

\subsection{Density During Process} 3.3.1. Effect of Time Changes on Density In this study, measurements of the sap juice's density were also carried out using plates

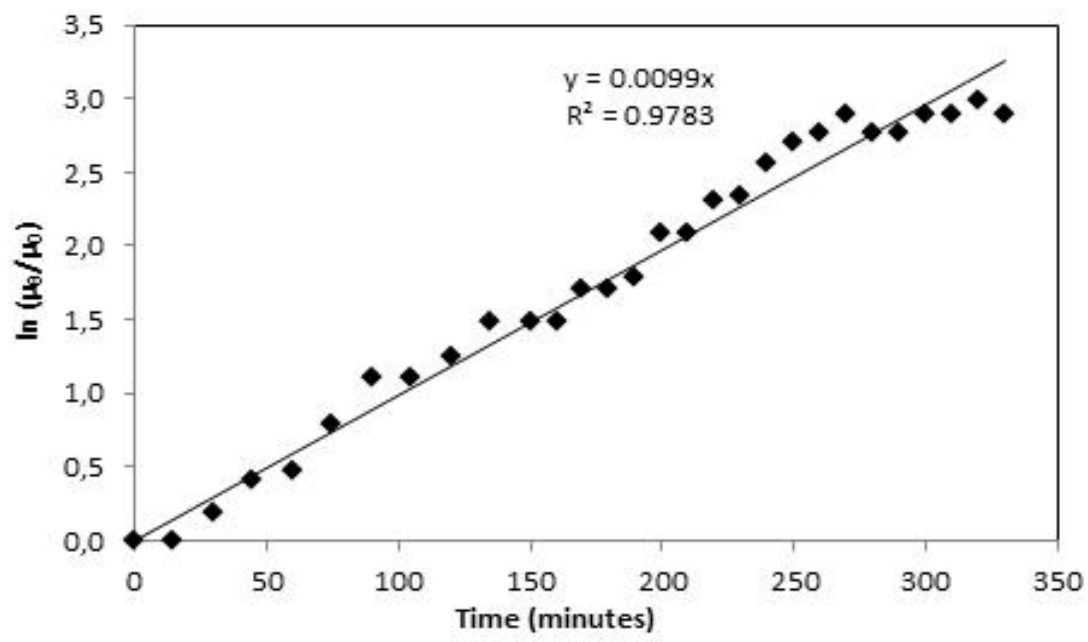

Figure 6. Graph of Coagulation Time $(\theta)$ Versus $\ln \left\{\left(\mu_{\theta}\right) /\left(\mu_{\mathrm{o}}\right)\right\}$ Coconut Sap Juice (Replication 2)

Table 4. The Constant of Observed Viscosity Changing Rate at $140^{\circ} \mathrm{C}$ and $2 \mathrm{~atm}$

\begin{tabular}{cccc}
\hline & Reps & $\begin{array}{c}\text { Observed } \boldsymbol{k}_{\boldsymbol{\mu}} \\
\left(\mathbf{m i n}^{-1}\right)\end{array}$ & $\begin{array}{c}\text { Average } \\
\left(\mathbf{m i n}^{-1}\right)\end{array}$ \\
\hline \multirow{3}{*}{ Coconut Sap } & 1 & 0.014 & \\
& 2 & 0.010 & 0.011 \\
\hline
\end{tabular}

Table 5. Gradient $(m)$ and $\mathrm{R}^{2}$ Values Between Predicted Viscosity and Observed Viscosity

\begin{tabular}{cccc}
\hline & Reps & $\boldsymbol{m}$ & $\mathbf{R}^{2}$ \\
\hline \multirow{3}{*}{ Coconut sap } & 1 & 0.014 & 0.7042 \\
& 2 & 0.010 & 0.8967 \\
& 3 & 0.010 & 0.8674 \\
\hline
\end{tabular}




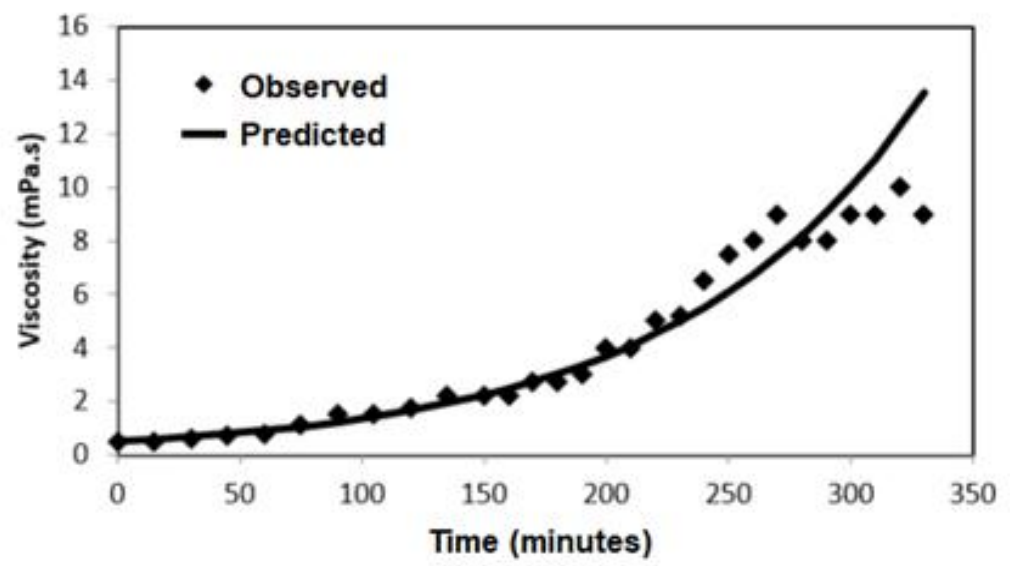

Figure 7. Changes of The Observed Viscosity and Predicted Viscosity Versus Time

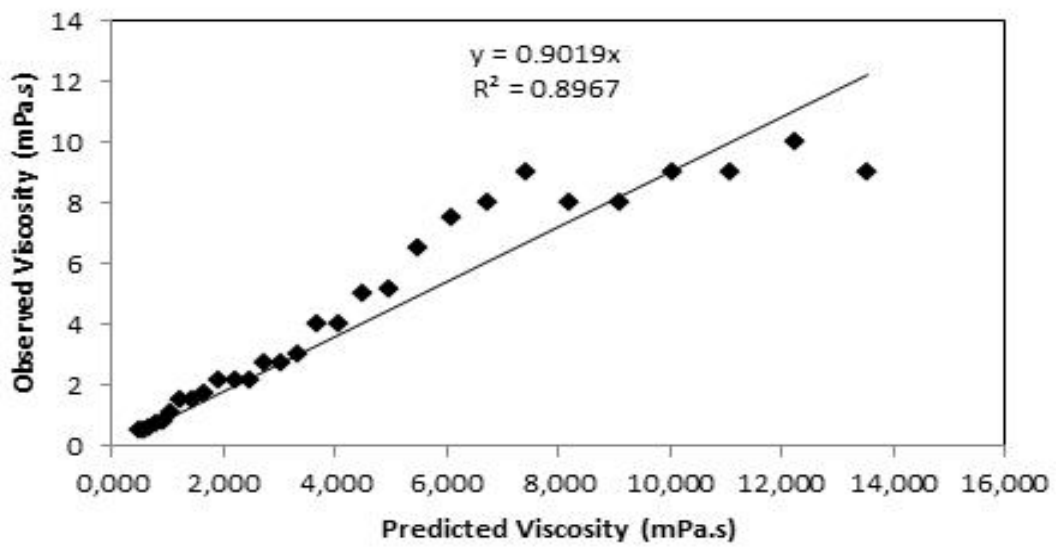

Figure 8. Comparison Between Predicted Viscosity and Observed Viscosity

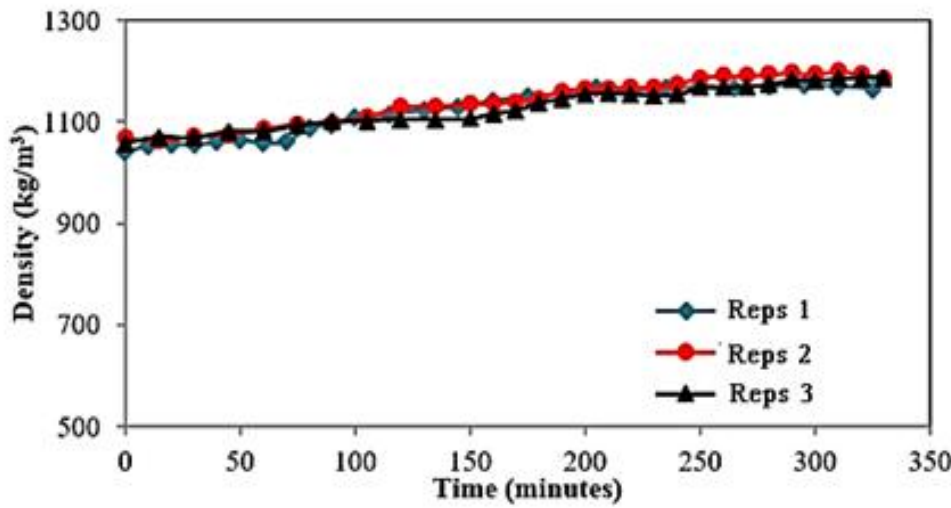

Figure 9. Density Changes During Thickening Time at $140^{\circ} \mathrm{C}$ and $2 \mathrm{~atm}$

measured in volume and weight. The material's density is calculated by subtracting the weight of the material in the plate by the weight of the empty cup and then dividing the plates' volume. Based on the measurement results, the sap juice's density during thickening is obtained for each time.

Figure 9 shows that the density of the sap juice tends to increase over time. When the evaporation event occurs, water is evaporated into the environment to increase dissolved solids. The thickening of the material indicates the increase in the number of dissolved solids over time. This resulted in increased density.

\subsubsection{The Density Change Rate}

The constant of density changing rate during thickening is determined by Eq. (11) by plotting a graph of the relationship between coagulation time $(\theta)$ and $\rho_{\theta}-\rho_{0}$, as shown in Figure 11, where the line equation in the figure shows that 
the constant rate of change in density is 0.4144 minutes $^{-1}$.

Furthermore, the rate constant of change in density is called the constant of observed density changing rate, presented in Table 6 . The observed density's constant changing rate is then substituted for equation 6 to obtain the predictive density equation.

\subsubsection{The Density Prediction}

Based on Table 6, the predicted density can be determined by substituting these constants into Eq. (11). The prediction density equation based on the constant change rate of observed density is as follows:

$$
\rho_{\theta}=(0.4496 \times t)+\rho_{0}
$$

Tabel 6. The Constant of Observed Density Changing Rate at $140^{\circ} \mathrm{C}$ and $2 \mathrm{~atm}$

\begin{tabular}{cccc}
\hline & Reps & $\begin{array}{c}\text { Observed } \boldsymbol{k}_{\boldsymbol{\rho}} \\
\left(\mathbf{m i n}^{-1}\right)\end{array}$ & $\begin{array}{c}\text { Average } \\
\left(\mathbf{m i n}^{-1}\right)\end{array}$ \\
\hline \multirow{3}{*}{ Coconut sap } & 1 & 0.4970 & \\
& 2 & 0.4376 & 0.4496 \\
\hline
\end{tabular}

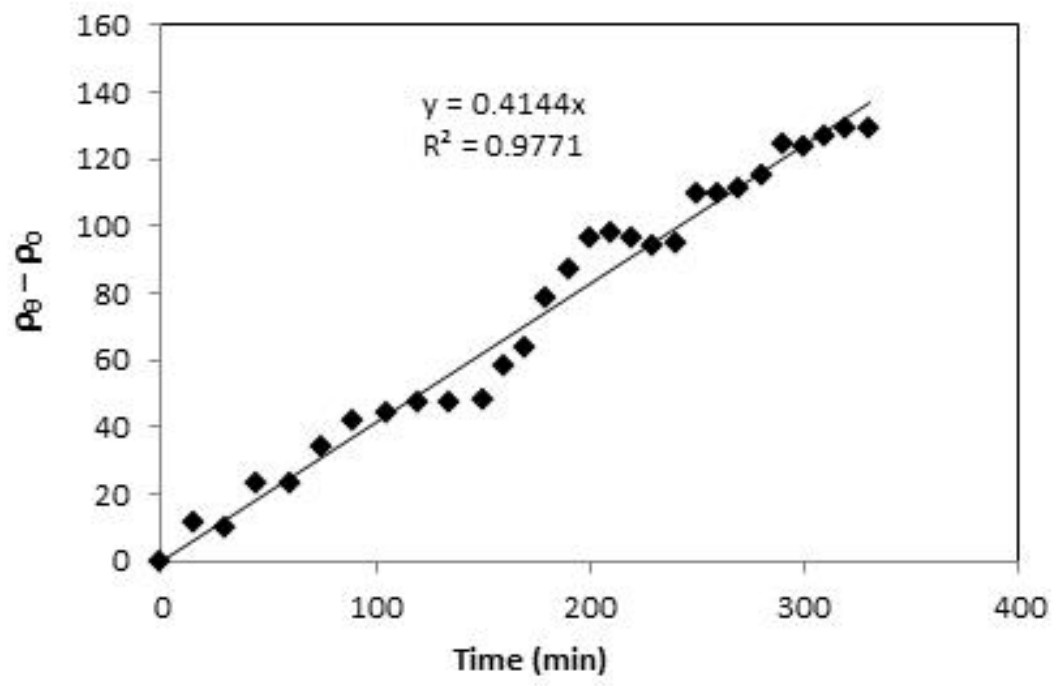

Figure 10. Graph of Coagulation Time $(\theta)$ Versus $\left(\rho_{\theta}-\rho_{0}\right)$ Coconut Sap Juice

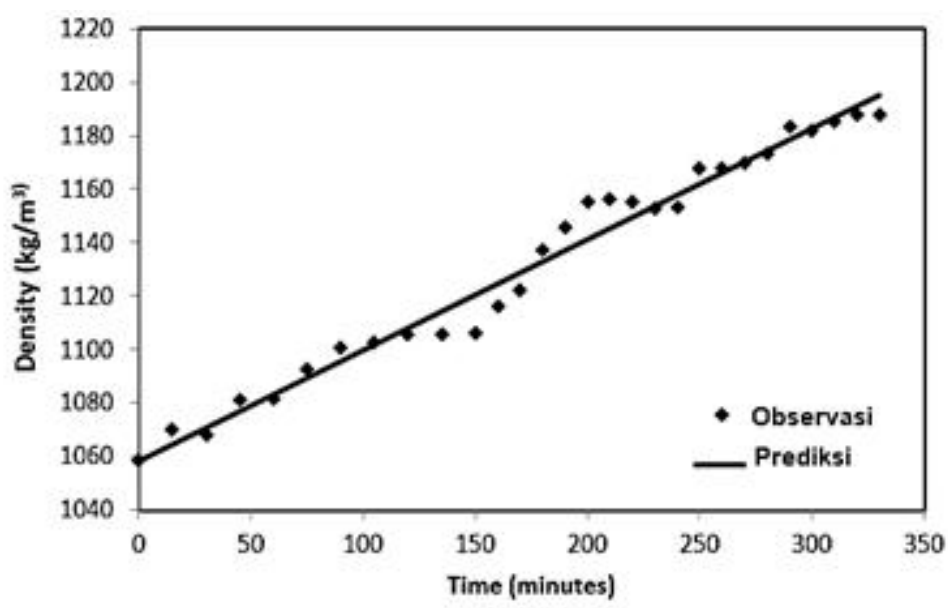

Figure 11. Changes of The Observed Density and Predicted Density Versus Time 
Table 7. Gradient and $\mathrm{R}^{2}$ Values Between Predicted Density and Observed Density

\begin{tabular}{lccc}
\hline & Reps & $\mathbf{m}$ & $\mathbf{R}^{2}$ \\
\hline \multirow{3}{*}{ Coconut sap } & 1 & 1.002 & 0.898 \\
& 2 & 0.999 & 0.963 \\
& 3 & 1.000 & 0.977 \\
\hline
\end{tabular}

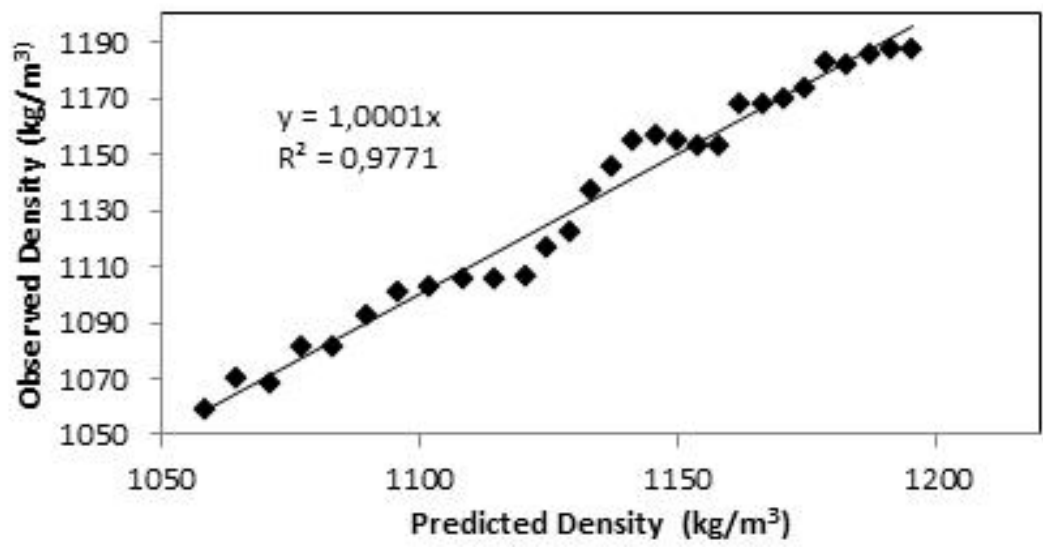

Figure 12. Comparison Between Predicted Density and Observed Density

Furthermore, the predicted and observed density are expressed in a graph versus time to see the proximity of the line between the predicted density and the observed density. The following graph shows the change in the measurement result (observation) with the predicted density.

The figure above shows that the predicted density is quite close to the observed density. This is shown by the graph line between the predicted density and the observed density, whose proximity is almost coincided.

Figure 12 compares the predicted density to the density of the measurement results, which, based on the coefficient of determination $\left(\mathrm{R}^{2}\right)$, is 0.898 to 0.977 . This shows that the points formed between the measured (observed) density and calculated (predicted) results are almost adjacent to the linear line.

\section{CONCLUSION}

The mathematical model can accurately predict changes in coconut sap's physical properties during the process in a vacuum evaporator. In this study, the evaporation process was carried out at a temperature of $140^{\circ} \mathrm{C}$ and a pressure of 2 $\mathrm{atm}$. The approach based on the constant rate of change Brix, viscosity, and density results in a high coefficient of determination $\left(\mathrm{R}^{2}\right)$ between the observed vs. predicted data. The prediction model Brix $C_{\theta}=\left\{\left(C_{0}-C_{e}\right) \cdot \exp (0.0067 \cdot t)\right\}+C_{e^{\prime}}$ is produced by analogy to Newton's Law of Cooling. The graph of the change in viscosity from the observations is exponential. Therefore, the prediction model for coconut sap's viscosity is determined by first-order kinetics theory, so the viscosity prediction model is $\mu_{\theta}=\mu_{0} \cdot \exp (0.011 \cdot t)$. Meanwhile, the density prediction model is determined by a zero-order kinetics theory formula because changes in the density of the observations result in a linear graph. The mathematical model of coconut sap density during cooking in the evaporator is $\rho_{\theta}=$ $(0.4496 \cdot t)+\rho_{0}$.

\section{REFERENCES}

Burhanuddin, R. 2005. Prospek Pengembangan Usaha Koperasi dalam Produksi Gula Aren. Makalah Sains, Jakarta.

Geankoplis, C. J. 1995. Transport Process and Unit Operations (Third Edition). Simon \& Schuster (Asia) Pte Ltr.

Hamzah, N., and Hazbullah. 1997. Evaluasi Mutu Gula Semut yang Dibuat dengan Menggunakan Beberapa Bahan Pengawet. 
Prosiding Seminar Teknologi Pangan. Universitas Andalas. Padang.

Hariono, B., Kurnianto, M., Bakri, A., Ardiansyah, M., and Wijaya, R. 2018. Improvement of Sensory and Chemistry Quality of Fried Edamame by Freezing. IOP Conference Series: Earth and Environmental Science, 207, 012048. https://doi.org/10.1088/ 1755-1315/207/1/012048

Haryanto, A., Saputra, T. W., Telaumbanua, M., and Gita, A. C. 2020. Application of Artificial Neural Network to Predict Biodiesel Yield from Waste Frying Oil Transesterification. Indonesian Journal of Science \& Technology, 5(1): 62-74.

Heldman, D. R. 2012. Food Process Engineering (Second Edition). The AVI Publishing Company, Inc.

Marsigit, W. 2005. Penggunaan Bahan Tambahan Pada Nira dan Mutu Gula Aren yang Dihasilkan di Beberapa Sentra Produksi di Bengkulu. Jurnal Penelitian UNIB, 11(1): 42-48.
Santoso, H. B. 1993. Pembuatan Gula Kelapa. Kanisius.

Singh, A. P., Hedley, M. E., Page, D. R., Han, C. S., and Atisongkroh, K. 1992. Microbial degradation of CCA-treated cooling tower timbers. IAWA, 13: 215-231.

Telaumbanua, M., Haryanto, A., Wisnu, F. K., Lanya, B., and Wiratama, W. 2021. Design of Insect Trap Automatic Control System for Cacao Plants. Procedia Environmental Science, Engineering and Management, 8(1): 167-175.

Wirakartakusumah. 1989. Prinsip Teknik Pangan. Bogor IPB Press. http:// $\mathrm{k}$ i n.p e r p u s n a s.go.i d / Data.aspx?pId=3760\&pRegionCode=JIPKMAL\& pClientId=111

Xia, Q., Li, S. Z., W. Chen, H., B. Xin, Y., and Huang, M. T. 2011. Chemical Composition Changes of Post-Harvest Coconut Inflorescence Sap During Natural Fermentation. African Journal of Biotechnology, 100(66): 14999-15005. 